\title{
Pelacakan Objek Bergerak Berdasarkan Pendekatan Adaptive Threshold untuk Alpha Matting Menggunakan Metode K-Means
}

\author{
Rofiq Harun \\ Fakultas Ilmu Komputer \\ Universitas Ichsan Gorontalo \\ Jln. Drs. Achmad Nadjamudin No.1, Kota Gorontalo, Kode Pos : 96115 \\ e-mail : rohanx@ @rogrammer.net
}

\begin{abstract}
Abstrak-Pelacakan objek merupakan kegiatan penting dalam bidang computer vision yang memiliki banyak aplikasi bidang interaksi manusia dan komputer, pengawasan, ruang yang cerdas dan pencitraan medis. Dalam bentuk yang paling sederhana, pelacakan dapat didefinisikan sebagai masalah memperkirakan lintasan objek dalam bidang gambar ketika bergerak di sekitar scene. Pelacakan obyek udah banyak dilakukan oleh para peneliti sebelumnya, baik menggunakan representasi obyek, feature selection. Maka peneliti mengusulkan penelitian baru yaitu pencarian nilai threshold menggunakan metode kmeans. Kemudian di lanjutkan dengan proses matting. Dari percobaan menggunakan 15 data indoor dan 15 data outdoor, didapatkan nilai threshold menggunakan metode kmeansuntuk matting terbukti lebih baik dibandingkan dengan metode Otsu, FCM, maupun metode manual. Dimana nilai akurasi metode Otsu didapatkan nilai MSE sebesar 3,13E+02 pixel, nilai MSE untuk FCM didapat sebesar 5,22E+01 pixel, metode kmeans sebesar 4,00E+01 pixeldari beberapa frame yang dijadikan latihanmenggunakan metode kmeans menggunakan fungsi matting. Dan untuk dataset outdoor nilai rata-rata yang di dapat dengan metode Otsu didapatkan nilai MSE sebesar $1,38 E+02$ pixel, nilai MSE untuk FCM didapat sebesar $1,89 \mathrm{E}+02$ pixel, metode kmeans sebesar $1,27 \mathrm{E}+02$ pixel
\end{abstract}

Kata kunci: pelacakan objek bergerak, threshold, kmeans, matting

\section{Pendahuluan}

Pelacakan objek memainkan peranan penting dalam bidang computer vision, banyak dipergunakan dalam bidang interaksi manusia dan komputer, pengawasan, dan pencitraan medis. Dalam bentuk yang paling sederhana, pelacakan dapat didefinisikan sebagai suatu hal dalam memperkirakan lintasan objek dalam bidang gambar ketika bergerak di sekitar frame [1].

Pelacakan objek telah menarik perhatian yang signifikan dikarenakan dapat melakukan berbagai proses yang luas, termasuk kecerdasan dalam video pengawasan, interface mesin dan manusia, serta bidang robotika. Banyak kemajuan telah dibuat dalam dua dekade terakhir. Namun, merancang metode pelacakan visual yang baik masih merupakan masalah yang terbuka. Tantangan dalam masalah pelacakan visual termasuk adanya bentuk bervariasi dan tampilan obyek yang bervariasi, oklusi, perubahan pencahayaan, adegan yang tidak beraturan, dan lain-lain[2].

Pelacakan objek yang telah dilakukan oleh beberapa peneliti sebelumnya dilakukan melalui: representasi objek, fitur gambar, gerakan tampilan serta bentuk objek yang dimodelkan. Pendekatan-pendekatan ini dilakukan berdasarkan konteks / lingkungan dimana pelacakan objek dilakukan dan penggunaan akhir dimana informasi pelacakan sedang dicari. Sejumlah besar metode pelacakan telah diusulkan yang mencoba untuk menjawab pertanyaan-pertanyaan untuk berbagai permasalahan[1].

Pelacakan objek menggunakan representasi objek pernah dilakukan beberapa peneliti salah satunya oleh Veeman[3], dimana peneliti menggunakan representasi poin yang diwakili oleh sebuah titik dalam melakukan pelacakan obyek. Dimana representasi titik ini sangat cocok untuk melacak obyek yang sangat kecil di dalam gambar. Pelacakan objek selain menggunakan representasi objek dapat dilakukan dengan seleksi fitur gambar, seleksi fitur gambar dapat dilakukan dengan menyeleksi tingkat warna seperti yang dilakukan oleh Comaniciu [4] , dalam penelitiannya peneliti menggunakan histogram warna dalam melaksanakan pelacakan terhadap obyek.

Untuk mencapai tingkat yang kuat dalam pelacakan objek yang bergerak bahkan dalam adegan yang dinamis, telah dilakukan beberapa metode dalam pengurangan background substraction (BGS). Metode BGS dapat diklasifikasikan menjadi tiga kategori: (1) metode berbasis pixel yang hanya menggunakan orintensity warna pixel informasi untuk membuat keputusan, (2) metode berbasis 
patch yang mempertimbangkan beberapa statistik lingkungan, (3) metode hybrid yang menggabungkan berbasis pixel dan metode BGS [5].

Keberhasilan satu metode dalam melakukan pelacakan objek terlepas dari substraksi background. Hal ini dikarenakan metode background substraction. baru-baru ini memiliki kemampuan dalam pemodelan pencahayaan yang berubah, kebisingan, dan gerakan periodik dari daerah latar belakang dan, karena itu, secara akurat dapat mendeteksi objek dalam berbagai kondisi[1]. Sehingganya tingkat keakuratan dalam melakukan ekstraksi di tunjang dengan metode yang handal. Metode yang digunakan dalam mengekstraksi background dan foreground adalah dengan menggunakan matting.

Matting merupakan metode untuk memisahkan foreground dan background dari satu gambar dengan memperkirakan opacity disebut alpha untuk setiap pixel dalam gambar. Ini merupakan tahapan penting dalam banyak gambar dan aplikasi video editing, karena dapat digunakan untuk secara akurat menyusun elemen foreground menjadi baru pada background gambar lainnya[6]. Pada dasarnya semua pendekatan yang dilakukan Matting adalah aktivitas kegiatan manusia[7].

Untuk mendapatkan nilai alpha matte banyak metode yang telah dilakukan oleh para peneliti dahulu, diantaranya melalui pendekatan threshold menggunakan Otsu Threshold Method[8]. Namun pada penelitian ini masih memiliki nilai varian yang tinggi dan jumlah pixel eror yang belum optimal. Sehingga peneliti mengganjurkan untuk melakukan penggunaan algoritma seperti k-means atau fuzzy c-means untuk memperoleh nilai threshold yang optimal.

Penelitian pencarian nilai threshold yang dilakukan oleh Rury [9] didapatkan nilai MSE yang lebih baik menggunakan metode FCM dibandingkan dengan pencarian nilai threshold dengan Otsu, yaitu dari nilai MSE menggunakan Otsu sebesar 5,E+03, setelah menggunakan metode FCM menjadi 2,E+03 dengan menggunakan dataset gambar yang sama pada metode Otsu. Hal ini menjadi dasar pada penelitian ini dengan menggunakan dataset yang berbeda dari peneliti sebelumnya, dimana didapatkan nilai MSE dengan menggunakan metode Otsu yakni 3,13E+02 pixel pada dataset indoor dan 1,38E+02 pixel pada dataset outdoor. Sehingga diharapkan akan didapatkan nilai akurasi yang lebih baik dengan menggunakan metode kmeans.

Penelitian yang dilakukan oleh z. hou et al 2006 [10], mengemukan bahwa kelemahan pada metode Otsu yang bias dalam mendeteksi letak lembah dari histogram sebuah citra, karena nilai threshold-nya cenderung mendekat pada class variance dan class probability yang lebih besar.

Penelitian ini memberikan usulan tentang penentuan threshold untuk pelacakan objek. Proses pelacakan objek diawali tahap pre-processing yaitu dengan melakukan pengaburan gambar (image blurring), selanjutnya menentukan threshold dengan menggunakan k-means sebagai proses thresholding yaitu proses untuk mengkonversi (converting) dari gambarabu-abu (grayscale) ke gambar binner yaitu gambar yang memiliki intensitas nilai piksel 0 dan 1 . Nilai yang didapat dari hasil threshold kmeans tadi akan dijadikan sebagai nilai alpha (a) dalam proses matting, setelah itu dilanjutkan melakukan bounding Box untuk proses pelacakan objek.

Pada penelitian ini menggunakan metode kmeans dikarenakan dinilai cukup efisien, yang ditunjukkan dengan kompleksitasnya $\mathrm{O}(\mathrm{tkn})$, dengan catatan $\mathrm{n}$ adalah banyaknya obyek data, $\mathrm{k}$ adalah jumlah cluster yang dibentuk, dan $\mathrm{t}$ banyaknya iterasi. Biasanya, nilai $\mathrm{k}$ dan $\mathrm{t}$ jauh lebih kecil daripada nilai n. Selain itu, dalam iterasinya, algoritma ini akan berhenti dalam kondisi optimum local[11].

K-Means merupakan salah satu metode data clustering non hirarki yang berusaha mempartisi data yang ada ke dalam bentuk satu atau lebih cluster/kelompok. Metode ini mempartisi data ke dalam cluster/kelompok sehingga data yang memiliki karakteristik yang sama dikelompokkan ke dalam satu cluster yang sama dan data yang mempunyai karakteristik yang berbeda dikelompokkan ke dalam kelompok yang lain. Adapun tujuan dari data clustering ini adalah untuk meminimalisasikan objective function yang diset dalam proses clustering, yang pada umumnya berusaha meminimalisasikan variasi di dalam suatu cluster dan memaksimalisasikan variasi antar cluster.

Sehingga fokus pada penelitian ini adalah menggunakan kmeans untuk penentuan threshold pada pelacakan objek. Sehingganya diharapkan metode ini mendapatkan hasil MSE yang lebih kecil.

\section{Studi Pustaka}

\section{A. Penelitian Terkait}

Penelitian matting objek telah banyak dilakukan oleh beberapa peneliti antara lain; Ruri Basuki [8], peneliti melakukan proses matting terhadap beberapa gambar dengan menggunakan metode Otsu untuk menghasilkan nilai threshold yang selanjutnya diberikan sebagai nilai alpha dalam "pulling matte”. Hasil objek foreground yang dipisahkan selanjutnya diukur kualitasnya dengan menggunakan MSE (Mean Squared Error) dengan nilai rata-ratanya sebesar 5,E+03. Dimana nilai $\alpha$ dalam alpha matting yang diberikan nilai konstanta $(0,3)$, dengan threshold Otsu dapat dilakukan secara adapatif terhadap beberapa kasus, meskipun masih memiliki nilai varian yang tinggi dan jumlah pixel error yang belum optimal. Kemudian peneliti membandingkan dengan metode lainnya, yang kali ini menggunakan metode FCM [9], dimana hasil yang didapat dalam penelitian ini menghasilkan nilai threshold yang lebih rendah dari Otsu, sehingga menggurangi jumlah nilai pixel. Pada hasil eksperimen yang dilakukan menggunakan metode Otsu di dapatkan nilai akurasi MSE sebesar 3,13E+02 pixel pada dataset indoor dan 1,38E+02 pixel pada dataset outdoor.

Pelacakan objek pernah dilakukan oleh beberapa peneliti, antara lain: Kim.et.al [12], mereka memperkenalkan sebuah algoritma untuk pelacakan objek dalam urutan video. Dalam rangka untuk mewakili objek untuk dilacak, mereka mengusulkan suatu model histogram warna spasial baru yang mengkode kedua distribusi warna dan informasi spasial. Dengan menggunakan model ini histogram warna spasial, metode voting berdasarkan umum Hough transform digunakan untuk memperkirakan lokasi objek dari frame ke frame. Yang diusulkan voting berbasis 
Metode, yang disebut metode voting pusat, permintaan setiap piksel dekat pusat objek sebelumnya mengeluarkan suara untuk menempatkan pusat objek baru dalam bingkai baru. Setelah lokasi objek diperoleh, metode proyeksi belakang digunakan untuk segmen objek dari latar belakang.

Selanjutnya, penelitian yang dilakukan oleh Zhao.et.al [13] mereka mengusulkan metode pelacakan baru, yang menyediakan objek akurat tersegmentasi batas. Langkah pertama dari metode yang diusulkan adalah untuk memodelkan obyek dan latar belakang menggunakan Gaussian Mix Model (GMM), dan ekstrak kontur kasar sesuai dengan fitur tepi objek. Dan maka negara dari objek, termasuk translasi, rotasi dan skala, diperkirakan menggunakan konteks bentuk pencocokan. Akhirnya, mereka mengambil metode pencocokan bentuk elastis untuk mengekstrak kontur yang tepat. yang diusulkan Metode ini cukup kuat untuk objek pelacakan dengan translasi, rotasi, perubahan skala dan parsial oklusi, dan juga dapat digunakan aplikasi pelacakan forreal-waktu. Percobaan pada kedua sintetis dan video terurut dunia nyata menunjukkan efektivitas dari metode yang diusulkan.

\section{B. Pelacakan Objek}

Pelacakan objek merupakan tugas penting dalam bidang visi komputer. Perkembangan komputer bertenaga tinggi, ketersediaan kualitas tinggi dan murahnya kamera video, dan meningkatnya kebutuhan untuk analisis video otomatis telah menghasilkan banyak minat dalam algoritma pelacakan objek. Ada tiga langkah utama dalam video Analisis: deteksi objek bergerak yang menarik, pelacakan benda-benda seperti dari France untuk membingkai, dan analisis trek objek untuk mengenali perilaku mereka.

\section{Grayscale}

Citra grayscale adalah suatu citra yang hanya memiliki warna tingkat keabuan. penggunaan citra grayscale dikarenakan membutuhkan sedikit informasi yang diberikan pada tiap pixel dibandingkan dengan citra warna.Intensitas dari citra grayscale disimpan dalam 8 bit integer yang memberikan 256 kemungkinan yang mana dimulai dari level 0 sampai dengan 255 (0 untuk hitam dan 255 untuk putih dan nilai diantaranya adalah derajat keabuan)[14]

\section{Threshold}

Thresholding adalah salah satu metode paling sederhana untuk memperoleh segmentasi gambar yang tajam [16]. Thresholding menghasilkan gambar biner, Dimana piksel obyek memiliki nilai 1 dan latar belakang memiliki nilai 0 , dengan demikian obyek akan muncul secara konsiten lebih cerah atau lebih gelap dari latar belakang. Dalam kondisi seperti itu, suatu obyek gambar biner dapat diperoleh dengan thresholding gambar gray-level.f( $x, y)$, adalah gambar memiliki tingkat intensitas dikelompokkan ke dalam dua mode dominan. Untuk mengekstrak objek dari latar belakang adalah dengan memilih nilai $\mathrm{T}$ ambang batas yang memisahkan mode ini. maka setiap titik $(\mathrm{x}, \mathrm{y})$, yang $\mathrm{f}(\mathrm{x}, \mathrm{y})$ $\geq \mathrm{T}$ disebut titik objek, jika tidak, titik ini disebut titik Latar [17]. Gambar thresholding $\mathrm{g}(\mathrm{x}, \mathrm{y})$ didefinisikan sebagai berikut:

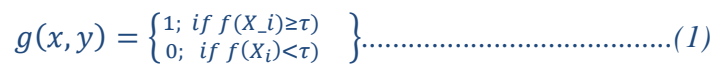

\section{E. Algoritma K-Means}

Algoritma K-Means adalah suatu metode penganalisaan data atau metode Data Mining yang melakukan proses pemodelan tanpa supervisi (unsupervised) dan merupakan salah satu metode yang melakukan pengelompokan data dengan sistem partisi.

Metode K-means berusaha mengelompokkan data yang ada ke dalam beberapa kelompok, dimana data dalam satu kelompok mempunyai karakteristik yang sama satu sama lainnya dan mempunyai karakteristik yang berbeda dengan data yang ada di dalam kelompok yang lain. Dengan kata lain, metode ini berusaha untuk meminimalkan variasi antar data yang ada di dalam suatu cluster dan memaksimalkan variasi dengan data yang ada di cluster lainnya.[11]

\section{F. Matting}

Matting image adalah metode untuk memisahkan foreground dan background dari satu gambar dengan memperkirakan opacity disebut alpha untuk setiap pixel dalam gambar. Ini merupakan tahapan penting dalam banyak gambar dan aplikasi video editing, karena dapat digunakan untuk secara akurat menyusun elemen foreground menjadi baru pada background gambar lainnya. [6]

Secara umum, warna $(i)$ dari gambar input $\left(C_{i}\right)$ dimodelkan sebagai kombinasi linear dari warna yang sesuai sebuah gambar foreground $\left(F_{i}\right)$ dan bacground ( $\left.B_{i}\right)$.

$$
C_{i}=\propto_{i} F_{i}+\left(1-\propto_{i}\right) B_{i}
$$

Dimana $\alpha_{i}$ adalah besaran pixel komponen opacity yang digunakan secara linear dalam memadukan foreground dan background.

Masalah anyaman digital secara inheren underconstrained karena memiliki lebih banyak tidak diketahui $(F, B$ dan $\alpha)$ dari kendala.

\section{MeTODE}

\section{A. Pengambilan Data}

Hasil pengumpulan data yang diambil dari pengamatan indoor secara langsung di salah satu koridor kampus, dikarenakan banyaknya mahasiswa yang melakukan aktivitas, serta pengamatan di outdoor terhadap aktivitas mobil yang lalu lalang. Ini untuk menguji sejauh mana tingkat penerapan threshold terhadap matting obyek yang dipengaruhi oleh tingkat pencahayaan dan kedekatan obyek terhadap background. Bentuk data berupa video dengan dimensi $352 \times 240$ pixel. 


\section{B. Model Eksperimen}

Eksperimen yang dilakukan dalam penelitian ini menggunakan matlab. Langkah-langkahnya seperti pada gambar 1 dibawah ini :

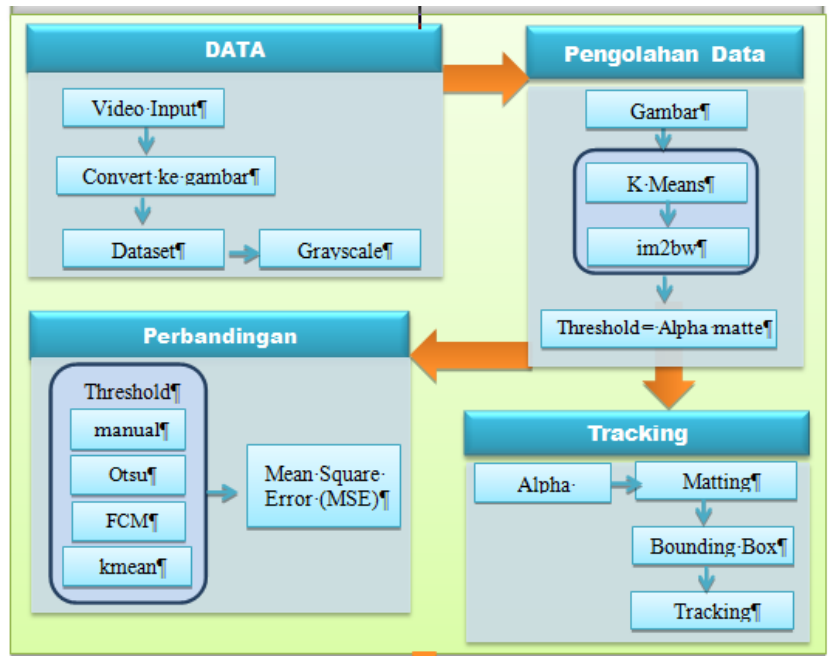

Gambar 1. Model Eksperimen

\section{Evaluasi}

Pengujian eksperimen yang dilakukan berupa pengukuran mean square error (MSE) dan prosentase keberhasilan pembagian region karakter. Validasi hasil yang didapatkan adalah tabel pengukuran MSE (data terlampir) dan grafik MSE per frame gambar serta presentase keberhasilan pembagian region karakter.

\section{Hasil dan Pembahasan}

\section{A. Dataset}

Hasil pengumpulan data yang diambil dari pengamatan indoor secara langsung di salah satu koridor kampus, dikarenakan banyaknya mahasiswa yang melakukan aktivitas, serta pengamatan di outdoor terhadap aktivitas mobil yang lalu lalang. Ini untuk menguji sejauh mana tingkat penerapan threshold terhadap matting obyek yang dipengaruhi oleh tingkat pencahayaan dan kedekatan obyek terhadap background. Bentuk data berupa video dengan dimensi 352 x 240 pixel diperlihatkan pada gambar 1 .

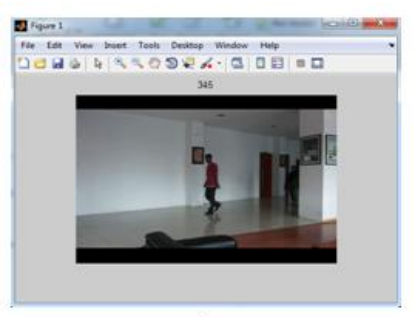

a)

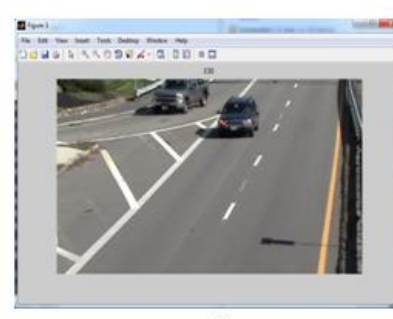

b)
Gambar 1. Dataset Video, a) Indoor, b) Outdoor

\section{B. Pemisahan dari Video ke Gambar}

Dalam proses pelacakan, terlebih dahulu video yang akan dilakukan proses pelacakan objek di ekstrak ke beberapa frame. Hal ini bertujuan untuk melakukan proses treshold, maupun segmentasi pada masing-masing frame.
Jumlah frame yang diekstrak yang digunakan dalam penelitian ini sejumlah 15 frame gambar diperlihatkan pada gambar 2 .
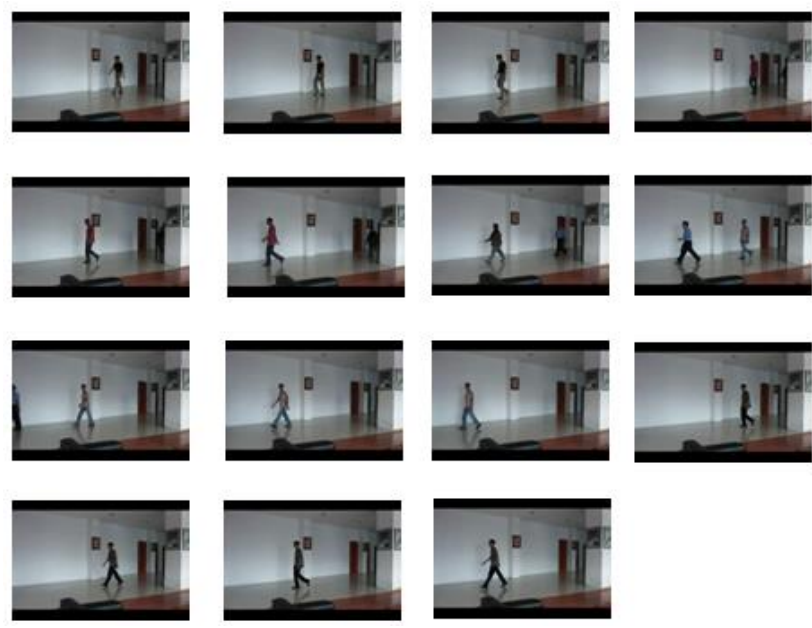

Gambar 2. Frame Dataset Indoor
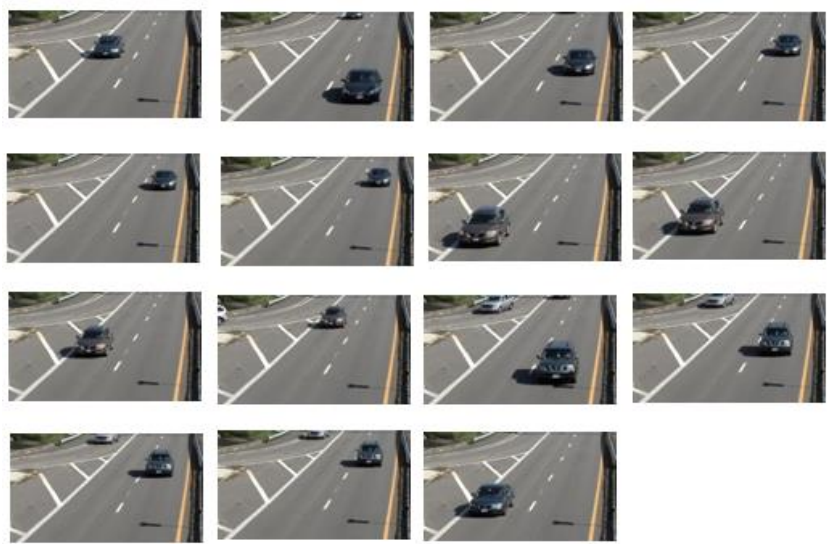

Gambar 3. Frame Dataset Outdoor

\section{Proses Threshold}

\section{1) Threshold Indoor}

Eksperimen yang dilakukan pada dataset indoor berjumlah 15 frame. Dataset ini kemudian di ujikan menggunakan beberapa metode, menggunakan metode manual, Otsu, FCM, dan terakhir adalah kmeans. Hal ini dimaksudkan untuk melihat perbandingan nilai threshold maupun nilai threshold yang dicapai pada sebuah frame dataset.

Berikut adalah hasil threshold yang didapat menggunakan keempat metode seperti pda table 1 dan table 2 .

\begin{tabular}{|c|c|c|c|c|}
\hline Frame & $\begin{array}{c}\text { Manual } \\
\text { untuk } \\
\text { matting }\end{array}$ & $\begin{array}{c}\text { Threshold } \\
\text { Otsu }\end{array}$ & $\begin{array}{l}\text { Threshold } \\
\text { FCM untuk } \\
\text { matting }\end{array}$ & $\begin{array}{c}\text { Threshold } \\
\text { Kmeans } \\
\text { untuk } \\
\text { matting }\end{array}$ \\
\hline 160.jpg & 0,5 & 0,31372549 & 0,558823529 & 0,654734848 \\
\hline 175.jpg & 0,5 & 0,31372549 & 0,554901961 & 0,653018466 \\
\hline 200.jpg & 0,5 & 0,305882353 & 0,550980392 & 0,661872633 \\
\hline
\end{tabular}




\begin{tabular}{|c|c|c|c|c|}
\hline Frame & $\begin{array}{c}\text { Manual } \\
\text { untuk } \\
\text { matting }\end{array}$ & $\begin{array}{c}\text { Threshold } \\
\text { Otsu }\end{array}$ & $\begin{array}{c}\text { Threshold } \\
\text { FCM untuk } \\
\text { matting }\end{array}$ & $\begin{array}{c}\text { Threshold } \\
\text { Kmeans } \\
\text { untuk } \\
\text { matting }\end{array}$ \\
\hline 315.jpg & 0,5 & 0,317647059 & 0,562745098 & 0,641678504 \\
\hline 350.jpg & 0,5 & 0,301960784 & 0,550980392 & 0,656344697 \\
\hline 380.jpg & 0,5 & 0,301960784 & 0,543137255 & 0,649005682 \\
\hline 485.jpg & 0,5 & 0,301960784 & 0,535294118 & 0,659434186 \\
\hline 575.jpg & 0,5 & 0,301960784 & 0,52745098 & 0,653361742 \\
\hline 615.jpg & 0,5 & 0,305882353 & 0,543137255 & 0,653586648 \\
\hline 630.jpg & 0,5 & 0,301960784 & 0,543137255 & 0,673082386 \\
\hline 650.jpg & 0,5 & 0,301960784 & 0,539215686 & 0,672419508 \\
\hline 765.jpg & 0,5 & 0,305882353 & 0,562745098 & 0,669992898 \\
\hline 775.jpg & 0,5 & 0,305882353 & 0,554901961 & 0,672857481 \\
\hline 795.jpg & 0,5 & 0,301960784 & 0,550980392 & 0,671768466 \\
\hline 805.jpg & 0,5 & 0,298039216 & 0,543137255 & 0,668702652 \\
\hline Average & $\mathbf{0 , 5}$ & $\mathbf{0 , 3 0 5 3 5 9 4 7 7}$ & $\mathbf{0 , 5 4 8 1 0 4 5 7 5}$ & $\mathbf{0 , 6 6 0 7 9 0 7 2}$ \\
\hline
\end{tabular}

Dari tabel 1, dapat dilihat nilai threshold dari kmeans yang paling tinggi, hal ini diakibatkan oleh tingkat pencahayaan ruangan yang di lakukan eksperimen. Setelah nilai threshold di dapat, langkah selanjutnya adalah mengukur nilai akurasinya keempat metode menggunakan MSE.

\begin{tabular}{|c|c|c|c|c|}
\hline Frame & $\begin{array}{c}\text { MSE } \\
\text { Manual }\end{array}$ & $\begin{array}{c}\text { Mean } \\
\text { Square } \\
\text { Error } \\
\text { Otsu }\end{array}$ & $\begin{array}{l}\text { Mean Square } \\
\text { Error FCM }\end{array}$ & $\begin{array}{c}\text { Mean } \\
\text { Square } \\
\text { Error } \\
\text { Kmeans }\end{array}$ \\
\hline 160.jpg & $1, \mathrm{E}+02$ & 2,E+02 & $3,18 \mathrm{E}+01$ & $3,25 \mathrm{E}+01$ \\
\hline 175.jpg & $6, \mathrm{E}+02$ & 2,E+02 & $4,43 \mathrm{E}+01$ & $4,67 \mathrm{E}+01$ \\
\hline 200.jpg & 4,E+01 & $3, \mathrm{E}+02$ & $9,99 \mathrm{E}+01$ & $9,64 \mathrm{E}+01$ \\
\hline 315.jpg & $3, \mathrm{E}+02$ & 1,E+01 & $1,23 \mathrm{E}+01$ & $1,35 \mathrm{E}+01$ \\
\hline 350.jpg & $6, \mathrm{E}+02$ & $3, \mathrm{E}+02$ & $3,37 \mathrm{E}+01$ & $3,12 \mathrm{E}+01$ \\
\hline 380.jpg & 6,E+02 & 4,E+02 & $7,03 \mathrm{E}+01$ & $4,76 \mathrm{E}+01$ \\
\hline 485.jpg & 7,E+02 & 4,E+02 & $5,45 \mathrm{E}+01$ & $3,29 \mathrm{E}+01$ \\
\hline 575.jpg & $6, \mathrm{E}+02$ & 5,E+02 & $4,59 \mathrm{E}+01$ & $3,50 \mathrm{E}+01$ \\
\hline 615.jpg & $3, \mathrm{E}+02$ & 5,E+02 & $1,38 \mathrm{E}+02$ & $5,37 \mathrm{E}+01$ \\
\hline 630.jpg & $3, \mathrm{E}+02$ & 4,E+02 & $3,83 \mathrm{E}+01$ & $3,41 \mathrm{E}+01$ \\
\hline 650.jpg & $2, \mathrm{E}+02$ & 4,E+02 & $6,36 \mathrm{E}+01$ & $3,50 \mathrm{E}+01$ \\
\hline 765.jpg & $2, \mathrm{E}+02$ & $1, \mathrm{E}+02$ & $2,89 \mathrm{E}+01$ & $2,85 \mathrm{E}+01$ \\
\hline 775.jpg & $3, \mathrm{E}+02$ & 4,E+02 & $3,51 \mathrm{E}+01$ & $3,34 \mathrm{E}+01$ \\
\hline 795.jpg & $6, \mathrm{E}+02$ & $2, \mathrm{E}+02$ & $3,14 \mathrm{E}+01$ & $2,99 \mathrm{E}+01$ \\
\hline 805.jpg & 7,E+02 & $5, \mathrm{E}+02$ & $5,42 \mathrm{E}+01$ & $5,04 \mathrm{E}+01$ \\
\hline Average & $4,11 \mathrm{E}+02$ & $3,13 E+02$ & $5,22 \mathrm{E}+01$ & $4,00 E+01$ \\
\hline
\end{tabular}

Dari data tabel 2, dapat dilihat hasil penggunaan metode kmeans untuk matting nilai akurasinya lebih rendah, dibandingkan menggunakan metode lainnya. Untuk lebih jelasnya dapat dilihat pada gambar 4.

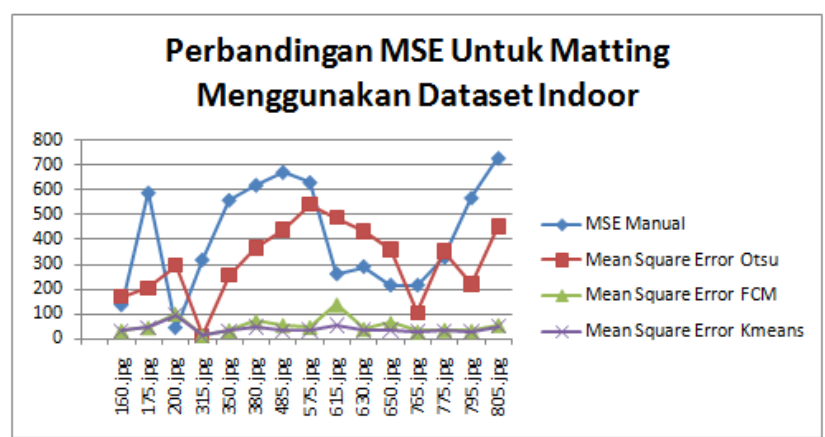

Gambar 4. Perbandingan Hasil MSE untuk Dataset Indoor

Dari grafik seperti gambar 4, nilai rata-rata yang di dapat dengan metode Otsu didapatkan nilai MSE sebesar 3,13E+02 pixel, nilai MSE untuk FCM didapat sebesar 5,22E+01 pixel, metode kmeans sebesar 4,00E+01 pixel. Hal ini disebabkan metode kmeans menghasilkan nilai threshold yang tinggi. Sehingga dapat di asumsikan penggunaan metode yang baik untuk dataset berada dalam ruangan, harus menghasilkan nilai threshold terbesar. Sehingga proses matting akan berhasil dengan baik.

\section{2) Threshold Outdoor}

Seperti pada eksperimen yang dilakukan pada dataset indoor, jumlah dataset pada outdoor juga berjumlah 15 frame. Dataset ini kemudian di ujikan menggunakan beberapa metode, baik menggunakan metode manual, Otsu, FCM, dan terakhir adalah kmeans. Hal ini dimaksudkan untuk melihat perbandingan nilai threshold maupun nilai akurasi yang dicapai pada sebuah frame dataset.

Berikut adalah hasil threshold yang didapat menggunakan keempat metode.

Tabel 3. Hasil Threshold Dataset Outdoor

\begin{tabular}{|l|c|c|c|c|}
\hline Frame & $\begin{array}{c}\text { Threshold } \\
\text { Manual }\end{array}$ & $\begin{array}{c}\text { Threshold } \\
\text { Otsu }\end{array}$ & $\begin{array}{c}\text { Threshold } \\
\text { FCM }\end{array}$ & $\begin{array}{c}\text { Threshold } \\
\text { Kmeans }\end{array}$ \\
\hline 136.jpg & 0,5 & 0,356863 & 0,68039216 & 0,12644965 \\
\hline 141.jpg & 0,5 & 0,356863 & 0,68431373 & 0,13265625 \\
\hline 151.jpg & 0,5 & 0,356863 & 0,68431373 & 0,15028646 \\
\hline 161.jpg & 0,5 & 0,356863 & 0,68823529 & 0,18613281 \\
\hline 201.jpg & 0,5 & 0,364706 & 0,68431373 & 0,11715278 \\
\hline 226.jpg & 0,5 & 0,360784 & 0,68039216 & 0,13831597 \\
\hline 236.jpg & 0,5 & 0,360784 & 0,68431373 & 0,15444878 \\
\hline 241.jpg & 0,5 & 0,360784 & 0,68431373 & 0,16638889 \\
\hline 306.jpg & 0,5 & 0,360784 & 0,68431373 & 0,11289931 \\
\hline 311.jpg & 0,5 & 0,360784 & 0,68431373 & 0,11644531 \\
\hline 316.jpg & 0,5 & 0,360784 & 0,68431373 & 0,12089844 \\
\hline 326.jpg & 0,5 & 0,356863 & 0,68431373 & 0,1349349 \\
\hline 336.jpg & 0,5 & 0,352941 & 0,68431373 & 0,16299479 \\
\hline 381.jpg & 0,5 & 0,360784 & 0,68039216 & 0,12232205 \\
\hline 401.jpg & 0,5 & 0,360784 & 0,68431373 & 0,15148003 \\
\hline Average & $\mathbf{0 , 5}$ & $\mathbf{0 , 3 3 6 7 6 5}$ & $\mathbf{0 , 6 4 1 0 5 3 9 2}$ & $\mathbf{0 , 1 3 0 8 6 2 9}$ \\
\hline
\end{tabular}


Dari tabel 3, dapat dilihat nilai threshold dari kmeans yang paling rendah, hal ini diakibatkan oleh tingkat pencahayaan, dan kedekatan obyek terhadap background yang di lakukan dalam eksperimen. Setelah nilai threshold di dapat, langkah selanjutnya adalah mengukur nilai akurasinya keempat metode menggunakan MSE

\begin{tabular}{|c|c|c|c|c|}
\hline Frame & $\begin{array}{c}\text { MSE } \\
\text { Manual }\end{array}$ & $\begin{array}{c}\text { Mean } \\
\text { Square } \\
\text { Error } \\
\text { Otsu }\end{array}$ & $\begin{array}{c}\text { Mean } \\
\text { Square } \\
\text { Error } \\
\text { FCM }\end{array}$ & $\begin{array}{c}\text { Mean Square } \\
\text { Error } \\
\text { Kmeans }\end{array}$ \\
\hline 136.jpg & 2,E+02 & 2,E+02 & 2,E+02 & $2,85 \mathrm{E}+02$ \\
\hline 141.jpg & 2,E+02 & $2, \mathrm{E}+02$ & $2, \mathrm{E}+02$ & $3,38 \mathrm{E}+02$ \\
\hline 151.jpg & $3, \mathrm{E}+02$ & $3, \mathrm{E}+02$ & 3,E+02 & $4,00 \mathrm{E}+02$ \\
\hline 161.jpg & $5, \mathrm{E}+02$ & 4,E+02 & $5, \mathrm{E}+02$ & $5,70 \mathrm{E}+02$ \\
\hline 201.jpg & $2, \mathrm{E}+02$ & $3, \mathrm{E}+02$ & $3, \mathrm{E}+02$ & $3,89 \mathrm{E}+02$ \\
\hline 226.jpg & $1, \mathrm{E}+02$ & $2, \mathrm{E}+02$ & $5, \mathrm{E}+01$ & $6,39 \mathrm{E}+02$ \\
\hline 236.jpg & $1, \mathrm{E}+02$ & $3, \mathrm{E}+02$ & $8, \mathrm{E}+01$ & $8,88 \mathrm{E}+02$ \\
\hline 241.jpg & $1, \mathrm{E}+02$ & 4,E+02 & $8, \mathrm{E}+01$ & $1,09 \mathrm{E}+03$ \\
\hline 306.jpg & 2,E+01 & $3, \mathrm{E}+01$ & 1,E+01 & $1,18 \mathrm{E}+02$ \\
\hline 311.jpg & $3, \mathrm{E}+01$ & 4,E+01 & $2, \mathrm{E}+01$ & $1,30 \mathrm{E}+02$ \\
\hline 316.jpg & $3, \mathrm{E}+01$ & $5, \mathrm{E}+01$ & $2, \mathrm{E}+01$ & $1,45 \mathrm{E}+02$ \\
\hline 326.jpg & 4,E+01 & 7,E+01 & $3, \mathrm{E}+01$ & $1,99 \mathrm{E}+02$ \\
\hline 336.jpg & $1, \mathrm{E}+02$ & $1, \mathrm{E}+02$ & 8,E+01 & $2,37 \mathrm{E}+02$ \\
\hline 381.jpg & 4,E+01 & $1, \mathrm{E}+02$ & 4,E+01 & $3,57 \mathrm{E}+02$ \\
\hline 401.jpg & 7,E+01 & $2, \mathrm{E}+02$ & 4,E+01 & $6,66 \mathrm{E}+02$ \\
\hline Average & $4,30 \mathrm{E}+02$ & $1,38 \mathrm{E}+02$ & $1,89 \mathrm{E}+02$ & $1,27 \mathrm{E}+02$ \\
\hline
\end{tabular}

Dari data tabel 4, dapat dilihat hasil penggunaan metode kmeans untuk matting nilai akurasinya lebih rendah, dibandingkan menggunakan metode lainnya. Untuk lebih jelasnya dapat dilihat pada grafik perbandingan berikut ini

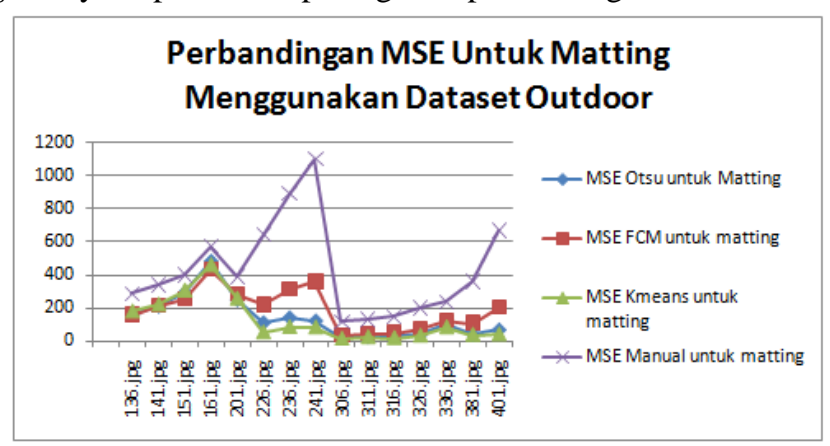

Gambar 5. Perbandingan MSE untuk Dataset Outdoor

Dari grafik di atas, nilai rata-rata yang di dapat dengan metode Otsu didapatkan nilai MSE sebesar 1,38E+02 pixel, nilai MSE untuk FCM didapat sebesar 1,89E+02 pixel, metode kmeans sebesar 1,27E+02 pixel. Hal ini disebabkan metode kmeans menghasilkan nilai threshold yang terkecil. Sehingga dapat di asumsikan penggunaan metode yang baik untuk dataset berada diluar ruangan, harus menghasilkan nilai threshold terkecil. Sehingga proses matting akan berhasil dengan baik..

Tetapi dalam eksperimen ini, masih menemukan beberapa permasalahan yang cukup signifikan, yakni proses waktu yang digunakan untuk melacak sebuah objek, baik menggunakan metode Otsu, FCM, maupun Kmeans. Dimana waktu yang diperlukan lama untuk melakukan proses pelacakan objek yang ada. Hal ini diakibatkan adanya proses matting pada masing-masing frame yang ada.

\section{KESIMPULAN}

Eksperimen yang diajukan sesuai dengan tujuan penelitian yaitu "Untuk mendapatkan nilai thresold dengan menggunakan metode K-means dalam meningkatkan proses matting, sehingga hasil dalam pelacakan obyek akan lebih baik.", dari hasil tersebut menggunakan metode metode Otsu didapatkan nilai MSE sebesar 3,13E+02 pixel, nilai MSE untuk FCM didapat sebesar 5,22E+01 pixel, metode kmeans sebesar 4,00E+01 pixeldari beberapa frame yang dijadikan latihanmenggunakan metode kmeans menggunakan fungsi matting. Dan untuk dataset outdoor nilai rata-rata yang di dapat dengan metode Otsu didapatkan nilai MSE sebesar $1,38 \mathrm{E}+02$ pixel, nilai MSE untuk FCM didapat sebesar 1,89E+02 pixel, metode kmeans sebesar 1,27E+02 pixel.

\section{REFERENS}

[1] A. Yilmaz, O. Javed, and M. Shah, "Object tracking," ACM Computing Surveys, vol. 38, no. 4, p. 13-es, Dec. 2006.

[2] B. Zhong, H. Yao, S. Chen, R. Ji, X. Yuan, S. Liu, and W. Gao, "Visual tracking via weakly supervised learning from multiple imperfect oracles," 2010 IEEE Computer Society Conference on Computer Vision and Pattern Recognition, pp. 1323-1330, Jun. 2010.

[3] C. J. Veenman, M. J. T. Reinders, and E. Backer, "Resolving motion correspondence for densely moving points," IEEE Transactions on Pattern Analysis and Machine Intelligence, vol. 23, no. 1, pp. 54-72, 2001.

[4] D. Comaniciu, S. Member, and V. Ramesh, "Kernel-Based Object Tracking," vol. 25, no. 5, pp. 564-577, 2003.

[5] B. Zhong, Y. Chen, Y. Chen, R. Ji, Y. Chen, D. Chen, and H. Wang, "Background subtraction driven seeds selection for moving objects segmentation and matting," Neurocomputing, vol. 103, pp. 132-142, Mar. 2013.

[6] S. Cho and H. Byun, "Dynamic curve color model for image matting," Pattern Recognition Letters, vol. 33, no. 7, pp. 920-933, May 2012.

[7] L. Cinque, P. Dondi, and L. Lombardi, "Automatic selection of regions of interest in a video by a depth-color image matting," Proceedings of the International Workshop on Video and Image Ground Truth in Computer Vision Applications VIGTA '13, pp. 1-8, 2013. 

Semantik, pp. 398-403, 2012.

[9] R. S. Basuki, "FUZZY C-MEANS ALGORITHM FOR ADAPTIVE THRESHOLD ON ALPHA MATTING," no. July, pp. 177-180, 2012.

[10] H.-F. Ng, "Automatic thresholding for defect detection," Pattern Recognition Letters, vol. 27, no. 14, pp. 1644-1649, Oct. 2006.

[11] G. Williams, "Overview Data Mining Algorithms Cluster Analysis What is Cluster Analysis? What is Cluster Analysis? What Is Good Clustering? Clustering Caveats Similarity and Dissimilarity Between Objects Minkowski distance," 2006.

[12] D.-H. Kim, H.-K. Kim, and S.-J. Ko, "Spatial color histogram based center voting method for subsequent object tracking and segmentation," Image and Vision Computing, vol. 29, no. 12, pp. 850-860, Nov. 2011.

[13] Z. Liu, H. Shen, G. Feng, and D. Hu, "Tracking objects using shape context matching," Neurocomputing, vol. 83, pp. 47-55, Apr. 2012.

[14] Z. S. Siddique, "FINGERPRINT IDENTIFICATION FOR CYRIX MEDIAGX BASED EMBEDDED SYSTEM," 2010.

[15] S. G. Wu, F. S. Bao, E. Y. Xu, Y. Wang, Y. Chang, and Q. Xiang, "A Leaf Recognition Algorithm for Plant Classification Using Probabilistic Neural Network," pp. 1-6.

[16] and P. N. R. J. C. Bezdek, K. James, R. Krisnapuram, "FUZZY MODELS AND ALGORITHMS FOR PATTERN RECOGNITION AND IMAGE PROCESSING," vol. 4. Springer US, 2005.

[17] R. C. Gonzales, R. E. Woods, and S. L. Eddins, "Digital image processing using matlab." Prentice Hall, 2009.

[19] Y. Wen, Y. Lu, J. Yan, and Z. Zhou, "An algorithm for license plate recognition applied to intelligent transportation system," Transportation, vol. 12, no. 3, pp. 830-845, 2011. 